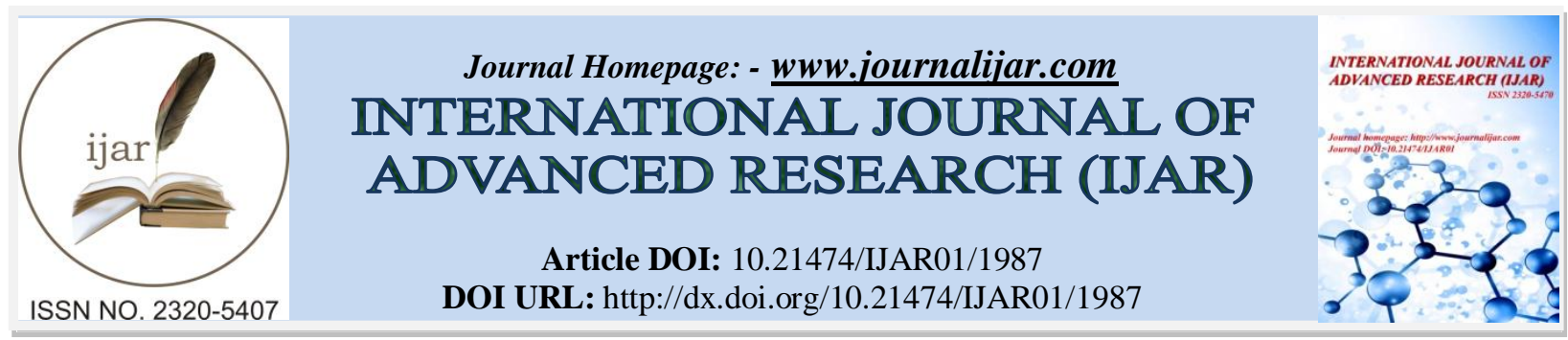

RESEARCH ARTICLE

\title{
General versus regional anaesthesia for caesarean section: A field study in four Riyadh hospitals, Saudi Arabia.
}

\begin{abstract}
Alaa Khalid Alatabani ${ }^{1}$ and Salwa Mohammed Bahkali ${ }^{2}$.
1. Obstetrics and Gynecology department, King Faisal Specialized hospital, Riyadh, Saudí Arabia.

2. King Saud Bin AbdulAziz University hospital, Nourah Bint AbdulRahman University, Riyadh, Saudí Arabia.
\end{abstract}

\section{Manuscript Info}

Manuscript History

Received: 12 August 2016

Final Accepted: 23 September 2016

Published: October 2016

Key words:-

General anaesthesia, regional anaesthesia, Caesarean Section, Riyadh, hospitals.

\section{Abstract}

Aim: To evaluate the preference of patients for elective cesarean section, also to know the most popular mode of anesthesia (spinal or general anesthesia), also to determine the relationship between anaesthesia type for caesarean section and patient satisfaction postoperation, degree of need for postoperative analgesia, and the future choice of type of anesthesia.

Method: This was a cross-sectional analytical study. The questionnaire distributed in Arabic on (400) mothers having elective caesarean section at four hospitals in Riyadh city, Saudi Arabia

Results: Majority of patients $(68.70 \%)$ had general anesthesiain the previous caesarean operation, while (68. $50 \%$ \%) had spinalanesthesia.Also there are a relationship between anaesthesia type for caesarean section and both patient satisfaction after the operation and degree of need for postoperative analgesia, where spinal anesthesia increases both patient satisfaction with anesthesia technique, and degree of patient need for postoperative analgesia after cesarean section.

Conclusion: Although spinal anesthesia is safer than general anaesthesia, being safer for both mother and fetus, allows the mother to be awake and immediately interact with her baby, but most of patients like general anesthesia because they are afraid of spinal anesthesia.

Copy Right, IJAR, 2016,. All rights reserved.

\section{Introduction:-}

Cesarean section is frequently becoming a popular mode of child delivery world-wide. The rate of Cesarean section could be as high as 18/100 in Africa to 32/100 deliveries in the United States (Declercq et al, 2011). The use of anesthesia makes a Cesarean delivery possible.

There are two general categories of anesthesia for Cesarean section: general anesthesia and regional anesthesia. Regional anesthesia includes both spinal and epidural techniques. Method of anaesthesia, spinal or general, has also faced many controversies due to its safety (Jawad et al, 2011). 
The use of general anesthesia has fallen dramatically in the past few decades and now accounts for only about 5 percent of Cesarean deliveries in the United States and United Kingdom. In the sub-Saharan Africa, $80-90 \%$ of the Cesarean sections are performed under spinal anesthesia. Although spinal analgesia is now the mainstay of anesthesia in countries like India and parts of Africa, excluding the major centers, current usage of this technique is waning in the developed world, with epidural analgesia or combined spinal-epidural anesthesia emerging as the techniques of choice where the cost of the disposable 'kit' is not a challenge (Fyneface-Ogan et al, 2005).

Owing to development in anaesthesia, although general anaesthesia is considered much safer and is still the method of choice in certain situations like urgency of surgery, contraindication to regional anaesthesia (coagulopathy, maternal hypovolemia, failed regional anaesthesia) and maternal request (Harrad and Howell ,2000), but complications like Pulmonary aspiration is an important cause of maternal morbidity associated with general anesthesia, and one of the major reasons for the initial popularity of regional techniques by the anesthetists (Afolabi et al, 2006).

Regional anaesthesia now a day, has gained worldwide acceptance and its physiological effects provide a rationale for expecting a better outcome with this technique (Crawford and Anmette, 2001).

Spinal anaesthesia is relatively easy to perform, gives excellent anaesthesia with a low potential of toxicity. It is preferred as it allows mother to be awake and interact immediately after the birth of baby. Compared to general anesthesia it offers less maternal morbidity, ability to use few drugs, comparable less blood loss and provision of excellent pain control (Danelli et al, 2009).

However, Spinal anesthesia is not free from side effects and has its own complications like maternal hypotension, fetal cardiac decelerations, post-operative headache and patients at risk of heavy peripartum hemorrhage may not tolerate the hemodynamic effects of regional anesthesia (Jawad et al, 2011).

WHO suggests that general or regional anaesthesia does not have a clear superiority over each other when used during caesarean section. The choice of the method should be based on woman's preferences regarding some advantages and disadvantages of either approach and the availability of appropriate equipment and expertise to administer either type of anaesthesia

Published in 2006, a Cochrane review compared the effects of regional anaesthesia with those of general anaesthesia on maternal and infant outcomes. It includes 16 studies involving 1586 women. Appropriate randomized controlled trials were searched according to Cochrane protocol in December 2005.

The review found that the difference between the preoperative and postoperative hematocrit levels in women who had regional anaesthesia (spinal or epidural) for caesarean section was lower compared with those who had general anaesthesia. Similarly, women who received regional anaesthesia had less estimated blood loss compared with those who received general anaesthesia.

None of the included studies reported on wound infection or any other infection related to caesarean section operation.

Even though there was no difference in women's satisfaction level with the type of anaesthesia they received, more women said they would prefer to receive general anaesthesia for their next caesarean section operation (Bamigboye, 2007).

The aim of the present work is to evaluate the preference of patients for elective cesarean section, also to know the most popular mode of anesthesia (spinal or general anesthesia) and likings and disliking of patients regarding anesthesia, also to determinethe relationship between anaesthesia type for caesarean section and patient satisfaction post-operation, degree of need for postoperative analgesia, and the future choice of type of anesthesia. 


\section{Patients and Methods:-}

This was a cross-sectional analytical study conducted in four Riyadh hospitals (King Faisal Specialist Hospital, AlShemaisy Hospital, Dr. Sulaiman Al Habib Hospital, and King Khalid University Hospital) throughout the period March - May, 2016

Total of 400 purposive non-probability sample of pregnant woman that underwent caesarean sections was checked in this study. Inclusion criteria were age from 20 to 40 years, undergoing emergency caesarean section for fetal distress or any other reason, single pregnancy, and non suffering from high blood pressure, diabetes and heart disease. Those with twin pregnancy and suffering from coagulopathy were excluded from the study.

Closed-ended questionnaire was used. It was distributed in Arabic on the sample of the study, with assistance - if necessary - to clarify any of its paragraphs/questions.

All data was collected and analyzed. Data will be analyzed using the SPSS 17.0 (Statistical Package for the Social Sciences) software. Percentages and frequencies were calculated for all questions of the questionnaire. Also, Chisquare test was used for to assessment the relationship between anaesthesia type for caesarean section and patient satisfaction after the operation, degree of need for postoperative analgesia, and the future choice of type of anesthesia. Statistically significant value was assumed when p-value less was than 0.05 .

\section{Results:-}

The study included 400 patients. Their age ranged between 20 and 40 years. With regards to number of caesarean sections, 50.8\% of patients had two caesarean sections. Also data demonstrated that almost two-thirds of patients $(68.8 \%)$ had general anesthesia in the previous caesarean operation, while the remaining $31.2 \%$ had spinal anesthesia. (Table 1)

Table 1:- Preliminary data of patients $(\mathrm{N}=400)$.

\begin{tabular}{|c|c|c|c|}
\hline Characteristics & Sub- Characteristics & Frequency & Percentage \\
\hline \multirow[t]{5}{*}{ Age } & From 20 to 25 & 94 & $23.5 \%$ \\
\hline & Up to 25 to 30 & 142 & $35.5 \%$ \\
\hline & Up to 30 to 35 & 103 & $25.8 \%$ \\
\hline & Up to 35 to 40 & 61 & $15.2 \%$ \\
\hline & Total & 400 & $100 \%$ \\
\hline \multirow[t]{5}{*}{ Number of caesarean sections } & 1 time & 164 & $41.0 \%$ \\
\hline & 2 times & 203 & $50.8 \%$ \\
\hline & 3 times & 32 & $8.0 \%$ \\
\hline & 4 times and more & 1 & $0.2 \%$ \\
\hline & Total & 400 & $100 \%$ \\
\hline \multirow{2}{*}{$\begin{array}{l}\text { Type of anesthesia in the previous } \\
\text { caesarean operation }\end{array}$} & General Anesthesia & 275 & $68.8 \%$ \\
\hline & Spinal Anesthesia & 125 & $31.22 \%$ \\
\hline \multicolumn{2}{|l|}{$\begin{array}{ll} & \text { Total } \\
\end{array}$} & 400 & $100 \%$ \\
\hline
\end{tabular}

Table 2 showed that $46.8 \%$ of subjects didn't have enough information about the advantages and disadvantages of general and spinal anesthesia before their cesarean section whereas $31 \%$ of them have enough information. Of 400 patients, decision to have general or spinal anesthesia was taken due to medical reasons in majority of cases (89\%). Almost three quarters of women (72\%) have family history of general anesthesia during cesarean section

Table 2:- Answers of the study sample about type of anaesthesia used for caesarean section.

\begin{tabular}{|l|c|c|c|}
\hline \multicolumn{1}{|c|}{ Characteristics } & Sub- Characteristics & Frequency & Percentage \\
\hline \multirow{2}{*}{$\begin{array}{l}\text { Did you have enough information } \\
\text { about the advantages and } \\
\text { disadvantages of general and } \\
\text { spinal anesthesia before your } \\
\text { cesarean section ? }\end{array}$} & Yes & 124 & $31.0 \%$ \\
\cline { 2 - 4 } & No & 187 & $46.8 \%$ \\
\cline { 2 - 4 } $\begin{array}{l}\text { Your Decide about the type of } \\
\text { anesthesia was }\end{array}$ & To some extant & 89 & $22.2 \%$ \\
\cline { 2 - 4 } & & $\mathbf{4 0 0}$ & $\mathbf{1 0 0 \%}$ \\
\cline { 2 - 4 } & Personal & 44 & $11.0 \%$ \\
\cline { 2 - 4 } & Medical & 356 & $89.0 \%$ \\
\hline
\end{tabular}




\begin{tabular}{|c|c|c|c|}
\hline \multirow{3}{*}{$\begin{array}{l}\text { Most ladies in your family have } \\
\text { undergone to specific type of } \\
\text { anesthesia during cesarean section }\end{array}$} & General anesthesia & 288 & $72.0 \%$ \\
\hline & Spinal anesthesia & 112 & $28.0 \%$ \\
\hline & Total & 400 & $100 \%$ \\
\hline \multirow{4}{*}{$\begin{array}{l}\text { Before Caesarean section, you } \\
\text { were worried about }\end{array}$} & General anesthesia & 135 & $33.8 \%$ \\
\hline & Spinal anesthesia & 186 & $46.5 \%$ \\
\hline & $\begin{array}{l}\text { I didn't feel any fear toward any of } \\
\text { them }\end{array}$ & 79 & $19.75 \%$ \\
\hline & $\begin{array}{l}\text { Total } \\
\end{array}$ & 400 & $100 \%$ \\
\hline \multirow{3}{*}{$\begin{array}{l}\text { Before Caesarean section, the } \\
\text { doctor advised you to undergo }\end{array}$} & General anesthesia & 220 & $55.0 \%$ \\
\hline & Spinal anesthesia & 180 & $45.0 \%$ \\
\hline & Total & 400 & $100 \%$ \\
\hline \multirow{4}{*}{$\begin{array}{l}\text { Do you think that the decision of } \\
\text { choosing the type of anesthesia for } \\
\text { the caesarean section is difficult? }\end{array}$} & Yes & 184 & $46.0 \%$ \\
\hline & No & 67 & $16.8 \%$ \\
\hline & To some extant & 149 & $37.2 \%$ \\
\hline & Total & 400 & $100 \%$ \\
\hline \multirow{4}{*}{$\begin{array}{l}\text { Before cesarean section, you } \\
\text { listened to some health problems } \\
\text { related to }\end{array}$} & General anesthesia & 87 & $21.8 \%$ \\
\hline & Spinal anesthesia & 199 & $49.8 \%$ \\
\hline & $\begin{array}{l}\text { I didn't listen to any health problems } \\
\text { related to both types }\end{array}$ & 114 & $28.4 \%$ \\
\hline & Total & 400 & $100 \%$ \\
\hline \multirow{3}{*}{$\begin{array}{l}\text { Before cesarean section, I thought } \\
\text { that ............ is better with } \\
\text { respect to pain after operation. }\end{array}$} & General anesthesia & 319 & $79.8 \%$ \\
\hline & Spinal anesthesia & 81 & $29.2 \%$ \\
\hline & Total & 400 & $100 \%$ \\
\hline \multirow{3}{*}{$\begin{array}{l}\text { Before cesarean section, I thought } \\
\text { that ............. is better with } \\
\text { respect to the child health. }\end{array}$} & General anesthesia & 101 & $25.2 \%$ \\
\hline & Spinal anesthesia & 299 & $74.8 \%$ \\
\hline & Total & 400 & $100 \%$ \\
\hline
\end{tabular}

With respect to the concern of anesthesia type before caesarean section, $46.5 \%$ of patients were worried about spinal anesthesia, while $33.8 \%$ were worried about general anesthesia, and (19.8\%) didn't feel any fear toward any of them. Table 2

In addition, table 2 demonstrated that $55 \%$ of physicians advised their patients to undergo general anesthesia before cesarean section, while $45 \%$ of them advised the patients with spinal anesthesia. Of 400patients, $46 \%$ think that the decision of choosing the type of anesthesia for the caesarean section is difficult.

Almost half of patients (49.8\%) were listened before cesarean section to spinal anesthesia health problems whereas $21.8 \%$ of patients were listened to some health problems related to general anesthesia. Table 2

With respect to the pain after caesarean section, the majority of study sample (79.8\%) thought before cesarean section that general anesthesia is better than spinal anesthesia. With respect to the child health, the majority of study sample (74.8\%) thought before cesarean section that spinal anesthesia is better. Table 2

As illustrated in Table 3, there was statistically significant association between patient satisfaction with anesthesia technique after cesarean section and type of anesthesia in the last caesarean section, $p$-value $=0.027$. Also there was significant association between degree of need for postoperative analgesia after cesarean section and type of anesthesia in the last caesarean section, $\mathrm{p}$-value $=0.012$. While there weren't relationship between the next choice of anesthesia type and type of anesthesia in the last caesarean section, where $\mathrm{p}$-value $=0.163$. So there are a relationship between anaesthesia type for caesarean section and both patient satisfaction after the operation and degree of need for postoperative analgesia, where spinal anesthesiaincreases both patient satisfaction with anesthesia technique, and degree of patient need for postoperative analgesia after cesarean section. 
Table 3:- Assessment of relationship between anaesthesia type for caesarean section and patient satisfaction postoperation, degree of need for postoperative analgesia, and the next choice of anesthesia type.

\begin{tabular}{|c|c|c|c|c|c|c|}
\hline \multirow{2}{*}{$\begin{array}{c}\text { Type of } \\
\text { anesthesia in the } \\
\text { last caesarean } \\
\text { section }\end{array}$} & \multicolumn{3}{|c|}{$\begin{array}{l}\text { Patient satisfaction with anesthesia } \\
\text { technique after cesarean section }\end{array}$} & \multirow[t]{2}{*}{ Total } & \multirow[t]{2}{*}{$\begin{array}{c}\text { Chi- } \\
\text { Square }\end{array}$} & \multirow[t]{2}{*}{ P -Value } \\
\hline & Yes & $\begin{array}{c}\text { To some } \\
\text { extant }\end{array}$ & No & & & \\
\hline $\begin{array}{c}\text { General } \\
\text { anesthesia }\end{array}$ & $\begin{array}{c}119 \\
(43.27 \%)\end{array}$ & $\begin{array}{c}87 \\
(31.64 \%)\end{array}$ & $\begin{array}{c}69 \\
(25.09 \%)\end{array}$ & $\begin{array}{c}275 \\
(68.75 \%)\end{array}$ & \multirow[t]{3}{*}{7.242} & \multirow[t]{3}{*}{$0.027 *$} \\
\hline Spinal anesthesia & $\begin{array}{c}94 \\
(75.2 \%) \\
\end{array}$ & $\begin{array}{c}21 \\
(16.8 \%)\end{array}$ & $\begin{array}{c}10 \\
(8 \%)\end{array}$ & $\begin{array}{c}125 \\
(31.25 \%)\end{array}$ & & \\
\hline Total & $\begin{array}{c}213 \\
(53.25 \%)\end{array}$ & $\begin{array}{c}108 \\
(27 \%)\end{array}$ & $\begin{array}{c}79 \\
(19.75 \%)\end{array}$ & $\begin{array}{c}400 \\
(100 \%)\end{array}$ & & \\
\hline \multirow{2}{*}{$\begin{array}{c}\text { Type of } \\
\text { anesthesia in the } \\
\text { last caesarean } \\
\text { section }\end{array}$} & \multicolumn{3}{|c|}{$\begin{array}{c}\text { Degree of need for postoperative } \\
\text { analgesiaafter cesarean section }\end{array}$} & \multirow[t]{2}{*}{ Total } & \multirow[t]{2}{*}{$\begin{array}{l}\text { Chi- } \\
\text { Square }\end{array}$} & \multirow[t]{2}{*}{ P- Value } \\
\hline & High & Moderate & Low & & & \\
\hline $\begin{array}{c}\text { General } \\
\text { anesthesia }\end{array}$ & $\begin{array}{c}72 \\
(26.18 \%)\end{array}$ & $\begin{array}{c}141 \\
(51.28 \%)\end{array}$ & $\begin{array}{c}62 \\
(22.54 \%)\end{array}$ & $\begin{array}{c}275 \\
(68.75 \%)\end{array}$ & \multirow[t]{3}{*}{9.320} & \multirow[t]{3}{*}{$0.012^{*}$} \\
\hline Spinal anesthesia & $\begin{array}{c}69 \\
(55.2 \%)\end{array}$ & $\begin{array}{c}41 \\
(32.8 \%)\end{array}$ & $\begin{array}{c}15 \\
(12 \%)\end{array}$ & $\begin{array}{c}125 \\
(31.25 \%)\end{array}$ & & \\
\hline Total & $\begin{array}{c}141 \\
(35.25 \%)\end{array}$ & $\begin{array}{c}182 \\
(45.5 \%)\end{array}$ & $\begin{array}{c}77 \\
(19.25 \%)\end{array}$ & $\begin{array}{c}400 \\
(100 \%)\end{array}$ & & \\
\hline \multirow{2}{*}{$\begin{array}{c}\text { Type of } \\
\text { anesthesia in the } \\
\text { last caesarean } \\
\text { section }\end{array}$} & \multicolumn{3}{|c|}{ The next choice of anesthesia type } & \multirow{2}{*}{ Total } & \multirow{2}{*}{$\begin{array}{l}\text { Chi- } \\
\text { Square }\end{array}$} & \multirow[t]{2}{*}{ P- Value } \\
\hline & \multicolumn{2}{|c|}{$\begin{array}{c}\text { General } \\
\text { anesthesia }\end{array}$} & Spinal anesthesia & & & \\
\hline $\begin{array}{c}\text { General } \\
\text { anesthesia }\end{array}$ & \multicolumn{2}{|c|}{$\begin{array}{c}195 \\
(70.90 \%)\end{array}$} & $\begin{array}{c}80 \\
29.10 \%)(\end{array}$ & $\begin{array}{c}275 \\
(68.75 \%)\end{array}$ & \multirow[t]{3}{*}{2.58} & \multirow[t]{3}{*}{0.163} \\
\hline Spinal anesthesia & \multicolumn{2}{|c|}{$\begin{array}{c}86 \\
(68.8 \%)\end{array}$} & $\begin{array}{c}39 \\
(31.2 \%)\end{array}$ & $\begin{array}{c}125 \\
(31.25 \%)\end{array}$ & & \\
\hline Total & \multicolumn{2}{|c|}{$\begin{array}{c}281 \\
(70.25 \%)\end{array}$} & $\begin{array}{c}119 \\
(29.75 \%)\end{array}$ & $\begin{array}{c}400 \\
(100 \%)\end{array}$ & & \\
\hline
\end{tabular}

$\mathrm{P}$ Value is based on Chi-Square test $* \mathrm{p}$ - value Statistically significant $<0.05$

\section{Discussion:-}

Cesarean section can be performed under either general or regional anesthesia like spinal or epidural technique. The Obstetric anesthetist requires special training and skills to provide safe anesthesia. The anesthetic techniques and agents chosen should provide good anesthesia and analgesia with minimal effects on feto-maternal well-being (Solangi et al, 2012).

The choice of anesthesia for a cesarean section depends on the indication for operation, degree of urgency, choice of the patient and anesthesiologist. So, when choosing regional or general anesthesia for caesarean delivery, one must consider outcome for both the mother and the neonate. The relative risks of general and regional anesthesia must be assessed in cesarean sections (Mekonnen and Ahmed, 2016).

The spinal anesthesia is commonly considered as more practical and safer than other techniques like general and epidural because it is simple to administer, need of minimal monitoring, the dose of drugs required to induce spinal anesthesia is 1.5 milliliter, therefore unlikely to produce systemic effects in the baby so less neonatal exposure to depressant drugs, a decreased risk of maternal pulmonary aspiration and an awake mother at the birth of baby (Solangi et al, 2012). In the present study, patients thought that general anethesis is better as regards post-operative pain and spinal anaethesia is better as regards child health 
As with any regional technique the disadvantages are risks of an extensive block, fixed duration of anesthesia, hypotension and the risk of postdural puncture headache (Yadav et al, 2012).

The drugs required for general anesthesia are multiple, most of the drugs effect the baby in two ways: by direct effect from placental drug transfer and by indirect effect resulting from maternal physiological and biochemical changes, which appear to be much more important (Solangi et al, 2012). They may produce systemic effects in the baby like low Apgar score and sedation (Reynolds and Seed, 2005).

In this technique there are risks of difficult intubations, maternal pulmonary aspiration, delayed recovery, nausea and vomiting. The incidence of maternal mortality may reach up to $10 \%$ (Waris, et al 2005).

In the present study, it is observed that, most of patients like general anesthesia and they are afraid of spinal anesthesia while most of anesthetists like spinal anesthesia because of its safety towards patient and baby. The major cause of fear for spinal anesthesia is the illiteracy of patient and lack of knowledge of anesthesia.

Additionally, the current study revealed a relationship between anaesthesia type for caesarean section and patient satisfaction post-operation as the patient satisfaction post-caesarean section was more when spinal anaesthesia was used. The major cause is that regional anaesthesia offers reduced maternal mortality, more direct experience of childbirth and the capability to decrease blood loss, superior muscle relaxation, quick restoration of bowel function and provide excellent postoperative pain control.

Also this study reported presence of relationship between anaesthesia type for caesarean section and degree of need for postoperative analgesia. Where the perception of pain during the caesarean section was less when general anaesthesia was used when compared to spinal anaesthesia. The major cause is that general anesthesia reduces the patient feeling with pain post- caesarean section.

We concluded that, although spinal anesthesia is safer than general anaesthesia, being safer for both mother and fetus, allows the mother to be awake and immediately interact with her baby, but most of patients like general anesthesia because they are afraid of spinal anesthesia. This review suggests that both general and spinal anaesthesia could be considered for caesarean section delivery. The choice of the method should be based on the clinical condition of the woman, her informed choice and availability of appropriate equipment and expertise to administer either type of anaesthesia

\section{References:-}

1. Afolabi BB, Lesi FE and Merah NA (2006): Reginal versus general anaesthesia for cesarian section. Cochrane datd base system review (4).

2. Bamigboye AA (2007): Regional versus general anaesthesia for caesarean section: RHL commentary. The WHO Reproductive Health Library; Geneva: World Health Organization.

3. Crawford S and Anmette $M$ (2001): General anesthesia vsreginal anesthesia for cesarean section at the university hospital of West Indies. West Indian Med J; 50:39.

4. Danelli G, Fenalli G, Berti M, Cornini A and Lacava L (2009): Spinal roprivacaine or bupavicaine for cesarean delivery; Aprospective randomized double blind comparison. Regional anesthesia and pain medicine; 29: 221-26.

5. Declercq E, Young R, Cabral $\mathbf{H}$ and Ecker $\mathbf{J}$ (2011): Is a rising cesarean delivery rate inevitable? Trends in industrialized countries, 1987 to 2007. Birth, Vol. 38: 99-104.

6. Fyneface-Ogan, Mato CN and Odagme MT (2005): Anaesthesia for Caesarean section: a ten year review. World Anaesth, Vol. 8:18-21.

7. Harrad JA and Howell PA (2000): General anesthesia for cesarean section. J Current and Critical care. ; 11: 66-72.

8. Jawad Zahir, Shazia Syed, and Nadia Jabeen (2011): Maternal and Neonatal Outcome after Spinal versus General Anaesthesia .Ann. Pak. Inst. Med. Sci; 7(3): 115-118.

9. Mekonnen S, Ahmed S (2016) Effects of general anesthesia vs regional anesthesia on neonatal outcomes: A sSystemic review and mata analysis. Int J Anesth Res. 4(6), 261-271 
10. Reynolds F, Seed PT (2005): Anesthesia for cesarean section and neonatal acid-base status a meta analysis. Anesthesia 60:636-53

11. Solangi SA, Siddiqui SM, Khaskheli MS, Siddiqui MA (2012): Comparison of the effects of general vs spinal anesthesia on neonatal outcome. Anaesth Pain \& Intensive Care 16(1):18-23.

12. Waris S, Yousuf M, Ahmed RA, Shahid M (2002). An experience of spinal anesthesia versus general anesthesia. Surg Pak 7:25-7

13. Yadav BB, Agrawal A, Singh DK, Tutu S, Lakhani P, Sachan A, et al (2015): Study to see the effects of different volumes of epidural saline injection during spinal anesthesia. ejpmr, 2(5), 1607-1612. 